\title{
Synthesis and Antiviral Evaluation of 1'-Branched-5'-Norcarbocyclic Adenosine Phosphonic Acid Analogues
}

\author{
Chang Hyun Oh, ${ }^{\dagger}$ Kyung Ho Yoo, ${ }^{\dagger}$ and Joon Hee Hong ${ }^{*}$
}

\author{
BK21 Project Team, College of Pharmacy, Chosun University, Kwangju 501-759, Korea. *E-mail: hongjh@chosun.ac.kr \\ ${ }^{\dagger}$ Medicinal Chemistry Research Center, Korea Institute of Science and Technology, Seoul 136-791, Korea
}

Received June 17, 2010, Accepted July 7, 2010

\begin{abstract}
Novel 1'-methyl-5'-norcarbocyclic adenosine phosphonic acid analogues were synthesized using an acyclic stereoselective route from commercially available 3,3-diethoxy-propan-1-ol 4. The synthesized nucleoside phosphonate 19 and phosphonic acid $\mathbf{2 1}$ were subjected to antiviral screening against various viruses.
\end{abstract}

Key Words: Antiviral agent, 1'-Branched nucleoside, 5'-Nornucleoside, Phosphonic acid nucleoside

\section{Introduction}

Nucleosides play a major role in combating tumors and viruses, with modifications of natural nucleosides leading to novel antitumor and/or antiviral agents, including branched nucleosides such as DMDC, ${ }^{1} \mathrm{CNDAC},{ }^{2} \mathrm{ECyd}^{3}{ }^{3} 4^{\prime} \alpha-C$-ethenylthymidine, ${ }^{4}$ and $4^{\prime} \alpha$ - $C$-ethynylthymidine ${ }^{5}$ as potent antiviral or antitumor agents.

The 1'-substituted nucleosides such as angustmycin $\mathbf{1}^{6}$ and hydantocidin $2^{7}$ are herbicidal and affect plant growth (Figure 1). However, only a few examples of 1 '-substituted nucleosides of defined absolute stereochemistry are reported. ${ }^{8}$ The scarcity of examples of 1'-substituted nucleosides may be due to the synthetic difficulties for elaborating a necessary tertiary carbon center. We therefore developed efficient methodology to synthesize furanosyl or cyclopentane rings containing stereochemically

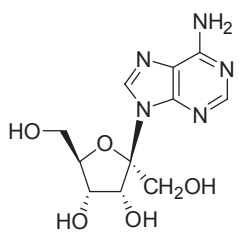

angustmycin C (1)

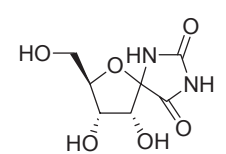

hydantocidin (2)

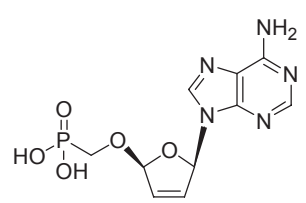

d4AP (3)
Figure 1. Structures of potent 1'-branched or 5'-nornucleoside analogues. defined tertiary carbons.

5'-Nornucleoside phosphonic acid analogues such as d4AP $\mathbf{3}^{9}$ as potential anti-HIV agents have encouraged the search for novel nucleosides in this class of compounds. A nucleoside 5'nornucleoside phosphonate analogue is essentially a nucleoside monophosphate analogue. ${ }^{10}$ The phosphonate has certain advantages over its phosphate counterpart as it is metabolically stable because its phosphorus-carbon bond is not susceptible to hydrolytic cleavage. ${ }^{11}$ Moreover, a phosphonate nucleoside can skip the requisite first phosphorylation, which is a crucial step for the activation of nucleosides. This is frequently a limiting event in the phosphorylation sequence, which ultimately leads to triphosphates.

Because 1'-branched nucleoside analogues and 5'-nornucleoside phosphate have excellent biological activities, we sought to synthesize and evaluate a novel class of nucleosides comprising 1'-methyl branched carbocyclic-5'-norcarbocyclic phosphonic acid.

\section{Results and Discussion}

The target compounds were prepared from commercially available starting material $\mathbf{4}$ as shown in Scheme 1. The alcohol functional group of $\mathbf{4}$ was protected with benzyl bromide to give the acetal derivative $\mathbf{5}$, which was subject to the acidic hydrolysis conditions using $p$-toluene sulfonic acid (PTSA) to give the aldehyde derivative 6 . Aldehyde functional 6 was sub-<smiles>CCOC(CCO)CCO</smiles>

4

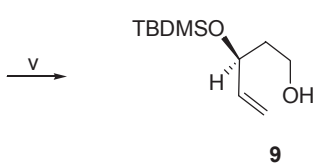<smiles>CCOCCC(CCOCC)OCC</smiles>

5

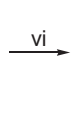

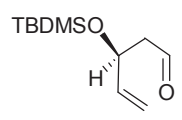

10
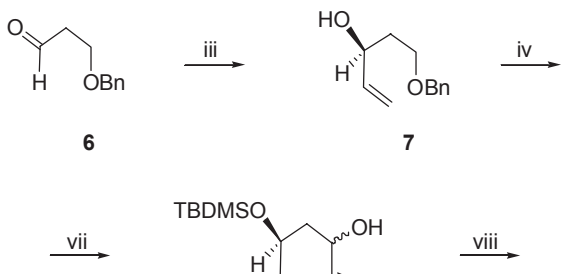

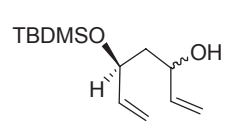

11
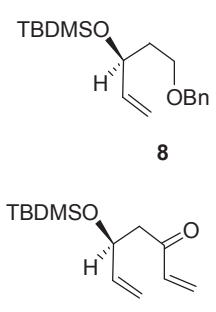

12

Reagents: i) BnBr, NaH, THF; ii) PTSA, $\mathrm{H}_{2} \mathrm{O}$ /acetone; iii) vinylMgBr, THF; iv) TBDMSOTf, 2,6-lutidine, $\mathrm{CH}_{2} \mathrm{Cl}_{2}$; v) $\mathrm{Li}, \mathrm{NH}_{3}$, THF; vi) $(\mathrm{COCl})_{2}$, DMSO, TEA, $\mathrm{CH}_{2} \mathrm{Cl}_{2}$; vii) vinylMgBr, THF; viii) $\mathrm{MnO}_{2}, \mathrm{CCl}_{4}$. 
ject to carbonyl addition using vinylmagnesium bromide to provide the tertiary alcohol derivative 7 as a racemic mixture. The corresponding tertiary hydroxyl group of 7 was successfully silylated using $t$-butyldimethylsilyl trifluoromethanesulfonate (TBDMSOTf) with 2,6-lutidine ${ }^{12}$ to give the fully protected compound 9 . Removal of the benzyl protecting group of $\mathbf{8}$ under dissolving metal reduction furnished desired alcohol $\mathbf{9}$, which was oxidized to the aldehyde 10 using Swern oxidation conditions (DMSO, oxalyl chloride, TEA). The aldehyde $\mathbf{1 0}$ was again subjected to nucleophilic Grignard conditions with vinylmagnesium bromide to give divinyl 11, which was subjected to allylic oxidation conditions $\left(\mathrm{MnO}_{2}, \mathrm{CCl}_{4}\right)$ to provide 12. Dienone 12 was subjected to addition by methyllithium in dry diethyl ether to give $\mathbf{1 3}$ as an inseparable isomer, which was subjected to ring-closing metathesis (RCM) conditions using 2 nd generation Grubbs catalyst ${ }^{13}$ to provide cyclopentenol 14a (41\%) and 14b (40\%), which were readily separated by silica gel column chromatography. The NOE experiments with cyclopentenols $14 \mathbf{a}$ and $\mathbf{1 4} \mathbf{b}$ confirmed these assignments. As expected, NOE enhancements were found between the cis-oriented hydrogens. Upon irradiation of $\mathrm{C}_{1}-\mathrm{CH}_{3}$, weak NOE patterns were observed at the proximal hydrogens of compound $\mathbf{1 4 b}$ $\left[C_{4}-\mathrm{H}(0.03 \%)\right]$ versus those of compound $14 \mathbf{a}\left[C_{4}-\mathrm{H}(0.06 \%)\right]$ (Figure 2).

To synthesize the desired 5'-norcarbocyclic adenine nucleoside analogue, the protected cyclopentenol 14b was treated with 6-chloropurine in the presence of diisopropyl azodicarboxylate (DIAD) and $\mathrm{PPh}_{3}$ to give $\mathbf{1 5}$ with a correct configuration. The choice of solvent system, temperature, and procedure are critical
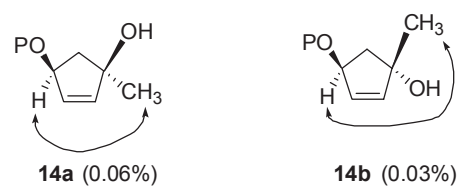

Figure 2. NOE difference between the hydrogens of $\mathbf{1 4 a}$ and $\mathbf{1 4} \mathbf{b}$. in the selective nucleobase coupling using Mitsunobu conditions (Scheme 2). Slow addition of diisopropyl azodicarboxylate (DIAD) to a mixture of cyclopentenol 14b, triphenylphosphine, and the 6-chloropurine in anhydrous dioxane-DMF mixture solvent gave a yellow solution that was stirred for $2 \mathrm{~h}$ at $-20{ }^{\circ} \mathrm{C}$ to give protected 6-chloropurine analogue $\mathbf{1 5}$. The silyl protection group was removed with tetrabutylammonium fluoride (TBAF) to give 16. Treatment of the nucleoside 16 with diethylphosphonomethyl triflate prepared from diethyl hydroxymethylphosphonate yielded the nucleoside phosphonate $17 .^{14}$ The chlorine group of $\mathbf{1 7}$ was then transformed to amine with methanolic ammonia at $70{ }^{\circ} \mathrm{C}$ to give a corresponding adenine phosphonate derivative $\mathbf{1 8} .^{15}$

The resultant nucleoside phosphonate mimics the overall shape and geometry of a nucleoside monophosphate. Bishydroxylation ${ }^{16}$ of the double bond in $\mathbf{1 8}$ was accomplished with a catalytic amount of osmium tetraoxide $\left(\mathrm{OsO}_{4}\right)$ and 4-methyl-morpholine $\mathrm{N}$-oxide (NMO) as the oxidant to give the dihydroxylated isomer $19(37 \%)$ as a major reaction product compared to minor isomer 20 (17\%) (Scheme 3). Their stereochemistries were also readily determined by NOE. These stereochemical outcomes suggest that two bulky groups such as the diethyl phosphonate and purine nucleobase reinforce the steric hindrance of the $\beta$-faces. ${ }^{17}$ Hydrolysis of 19 by treatment with bromotrimethylsilane in $\mathrm{CH}_{3} \mathrm{CN}$ in the presence of 2,6-lutidine gave an adenine phosphonic acid derivative $21{ }^{18}$

\section{Conclusions}

As shown in Table 1, the synthesized nucleoside phosphonate 19 and phosphonic acid 21 were subjected to antiviral screening against herpes simplex virus, coxsakie B virus, poliovirus, and human immunodeficiency virus according to the assay procedure. ${ }^{19}$ They only showed weak antiviral activity $\left(\mathbf{1 9}, \mathrm{EC}_{50}=\right.$ $62.7 \mu \mathrm{M})$ and $\left(\mathbf{2 1}, \mathrm{EC}_{50}=41.2 \mu \mathrm{M}\right)$ against herpes simples virus type 1 without cytotoxicity.

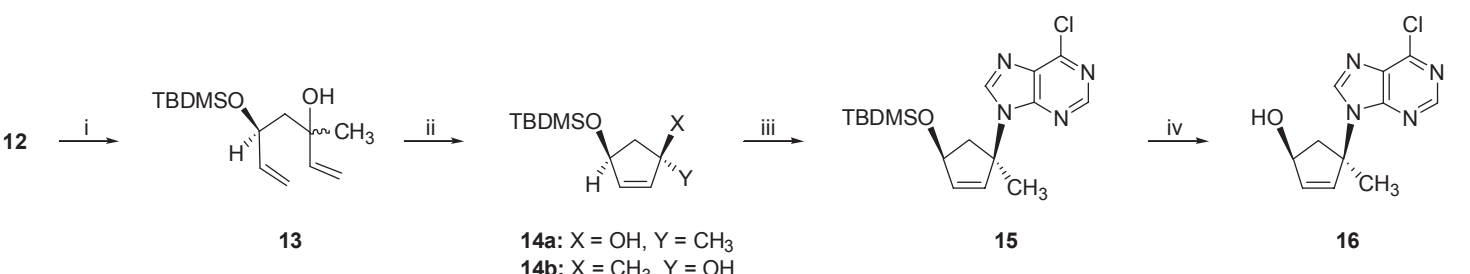

Reagents: i) MeLi, diethylether; ii) Grubbs (II) catalyst, $\mathrm{CH}_{2} \mathrm{Cl}_{2}$; iii) 6-chloropurine, DIAD, dioxane/DMF; iv) TBAF, THF.

Scheme 2. Synthesis of 5'-norcarbocyclic 6-chloropurine $\mathbf{1 6}$

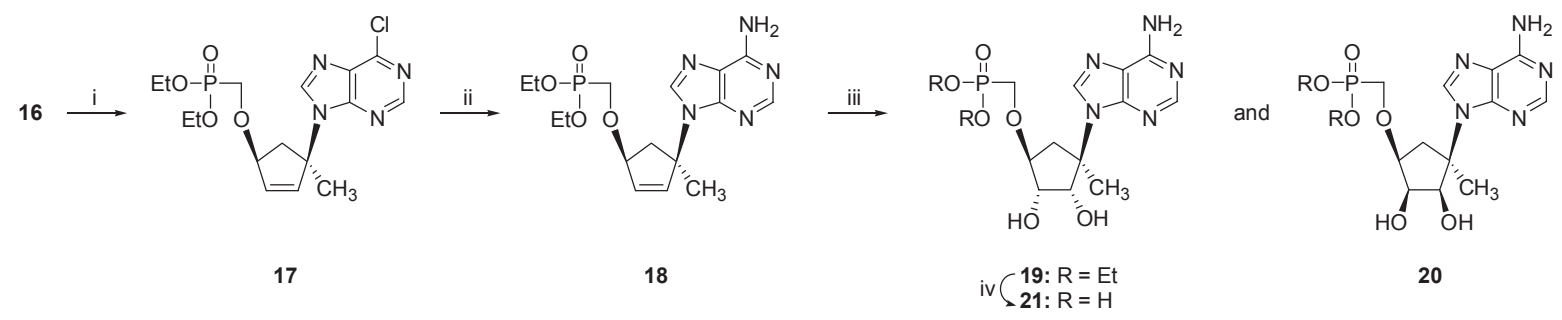

Reagents: i) (EtO) ${ }_{2} \mathrm{POCH}_{2} \mathrm{OTf}$, LiO-t-Bu, THF; ii) $\mathrm{NH}_{3} / \mathrm{MeOH}, 70{ }^{\circ} \mathrm{C}$; iii) $\mathrm{OsO}_{4}$, NMO, acetone/t-BuOH/H $\mathrm{H}_{2} \mathrm{O}$; iv) TMSBr, 2,6-lutidine, $\mathrm{CH}_{3} \mathrm{CN}$.

Scheme 3. Synthesis of target 5'-norcarbocyclic phosphonic acid analogues 
Table 1. Antiviral activity of synthesized compounds

\begin{tabular}{cccc}
\hline $\begin{array}{c}\text { Compound } \\
\text { No. }\end{array}$ & Virus & $\begin{array}{c}\text { Activity } \\
\mathrm{EC}_{50}(\mu \mathrm{M})\end{array}$ & $\begin{array}{c}\text { Cytotoxicity } \\
\mathrm{IC}_{50}(\mu \mathrm{M})\end{array}$ \\
\hline \multirow{4}{*}{$\mathbf{1 9}$} & HSV-1 & $\mathbf{6 2 . 7}$ & $>100$ \\
& coxsakie B & $>100$ & $>100$ \\
& Polio & $>100$ & $>100$ \\
& HIV-1 & $>100$ & $>100$ \\
$\mathbf{2 1}$ & HSV-1 & $\mathbf{4 1 . 2}$ & $>100$ \\
& coxsakie B & $>100$ & $>100$ \\
& Polio & $>100$ & $>100$ \\
& HIV-1 & 90 & 98 \\
\hline
\end{tabular}

On the basis of potent antiviral and antitumor activity of 1'-branched nucleoside analogues, we have accomplished the stereoselective synthesis of its carbocyclic version starting from 3,3-diethoxy-propan-1-ol. The synthesis of other nucleoside analogues with different nucleobases (T, C, U), their SATEprodrugs and stability study will be reported elsewhere.

\section{Experimental Section}

Melting points were determined on a Mel-temp II laboratory device and are uncorrected. NMR spectra were recorded on a JEOL 300 Fourier transform spectrometer (JEOL, Tokyo, Japan); chemical shifts are reported in parts per million $(\delta)$ and signals are reported as s (singlet), d (doublet), t (triplet), q (quartet), $\mathrm{m}$ (multiplet) and dd (doublet of doublets). UV spectra were obtained on a Beckman DU-7 spectrophotometer (Beckman, South Pasadena, CA, USA). MS spectra were collected in electrospray ionization (ESI) mode. The elemental analyses were performed using a Perkin-Elmer 2400 analyzer (Perkin-Elmer, Norwalk, CT, USA). TLC was performed on Uniplates (silica gel) purchased from Analtech Co. (7558, Newark, DE, USA). All reactions were carried out under an atmosphere of nitrogen unless otherwise specified. Dry dichloromethane, benzene, and pyridine were obtained by distillation from $\mathrm{CaH}_{2}$. Dry THF was obtained by distillation from $\mathrm{Na}$ and benzophenone immediately prior to use.

(3,3-Diethoxy-propoxymethyl)-benzene (5). To a stirred suspension of $\mathrm{NaH}(0.7 \mathrm{~g}, 29.16 \mathrm{mmol})$ in THF $(75 \mathrm{~mL})$, a solution of 4 (3.13 g, $21.15 \mathrm{mmol})$ in dry THF $(30 \mathrm{~mL})$ was added slowly, and stirred for $1 \mathrm{~h}$ at $\mathrm{rt}$. To this mixture, benzyl bromide (4.27 g, $25 \mathrm{mmol})$ was added, and stirred overnight at rt. The mixture was quenched using a saturated ammonium chloride solution $(10 \mathrm{~mL})$ and further diluted with water $(100 \mathrm{~mL})$. The mixture was extracted with EtOAc $(100 \mathrm{~mL})$ twice. The combined organic layer was washed with brine, dried over anhydrous $\mathrm{MgSO}_{4}$, and filtered. The filtrate was concentrated under reduced pressure, and the residue was purified by silica gel column chromatography (EtOAc/hexane, 1:10) to give compound 4 (4.33g, 86\%) as a colorless oil: ${ }^{1} \mathrm{H} \mathrm{NMR}\left(\mathrm{CDCl}_{3}, 300 \mathrm{MHz}\right) \delta$ 7.27-7.20 (m, 5H), $4.68(\mathrm{t}, J=6.0 \mathrm{~Hz}, 1 \mathrm{H}), 4.57(\mathrm{~s}, 2 \mathrm{H}), 3.71-$ $3.60(\mathrm{~m}, 6 \mathrm{H}), 1.98(\mathrm{~m}, 2 \mathrm{H}), 1.35(\mathrm{t}, J=6.8 \mathrm{~Hz}, 6 \mathrm{H}) ;{ }^{13} \mathrm{C} \mathrm{NMR}$ $\left(\mathrm{CDCl}_{3}\right) \delta 137.8,128.4,127.4,104.6,75.4,62.2,60.6,38.2$, 16.2 .

3-Benzyloxy-propionaldehyde (6). The mixture of acetal 5 (216.9 $\mathrm{mg}, 0.91 \mathrm{mmol}$ ) and $p$-toluenesulfonic acid (PTSA, $17.4 \mathrm{mg}, 0.092 \mathrm{mmol})$ in $10 \%$ aqueous acetone $(10 \mathrm{~mL})$ was heated overnight at $35-40{ }^{\circ} \mathrm{C}$, and then quenched by addition of triethylamine and concentrated in vacuo. The residue was extracted with ethylacetate, dried over anhydrous sodium sulfate, and concentrated to dryness. The residue was purified by silica gel column chromatography (EtOAc/hexane, 1:5) to give compound $\mathbf{6}(118 \mathrm{mg}, 79 \%)$ as a colorless oil: ${ }^{1} \mathrm{H} \mathrm{NMR}\left(\mathrm{CDCl}_{3}\right.$, $300 \mathrm{MHz}) \delta 9.87(\mathrm{~s}, 1 \mathrm{H}), 7.25-7.19(\mathrm{~m}, 5 \mathrm{H}), 4.67(\mathrm{~s}, 2 \mathrm{H}), 3.69$ $(\mathrm{t}, J=7.0 \mathrm{~Hz}, 2 \mathrm{H}), 2.58(\mathrm{t}, J=7.0 \mathrm{~Hz}, 2 \mathrm{H}) ;{ }^{13} \mathrm{C} \mathrm{NMR}\left(\mathrm{CDCl}_{3}\right)$ $\delta 200.8,138.1,128.8,127.5,74.6,63.7,46.4$.

( \pm )-5-Benzyloxy-pent-1-en-3-ol (7). To a solution of 6 (1.55 $\mathrm{g}, 9.44 \mathrm{mmol})$ in dry THF $(20 \mathrm{~mL})$ was slowly added vinylMgBr (11.32 mL, 1.0 M solution in THF) at $-20^{\circ} \mathrm{C}$ and stirred for $3 \mathrm{~h}$ at the same temperature. Saturated $\mathrm{NH}_{4} \mathrm{Cl}$ solution $(10 \mathrm{~mL})$ was added to the mixture, which was slowly warmed to rt. The mixture was further diluted with water $(100 \mathrm{~mL})$ and extracted with EtOAc $(100 \mathrm{~mL})$ two times. The combined organic layer was washed with brine, dried over anhydrous $\mathrm{MgSO}_{4}$, filtered, and evaporated under reduced pressure. The residue was purified by silica gel column chromatography (EtOAc/hexane, 1:15) to give $7(1.50 \mathrm{~g}, 83 \%)$ as a colorless oil: ${ }^{1} \mathrm{H} \mathrm{NMR}\left(\mathrm{CDCl}_{3}\right.$, $300 \mathrm{MHz}) \delta$ 7.28-7.23 (m, 5H), 5.91-5.83 (m, 1H), 5.25 (d, $J=$ $12.2 \mathrm{~Hz}, 1 \mathrm{H}), 5.12$ (d, $J=7.0 \mathrm{~Hz}, 1 \mathrm{H}), 4.64(\mathrm{~s}, 2 \mathrm{H}), 3.90(\mathrm{~m}$, $1 \mathrm{H}), 3.39(\mathrm{t}, J=6.8 \mathrm{~Hz}, 2 \mathrm{H}), 1.67(\mathrm{~m}, 2 \mathrm{H}) ;{ }^{13} \mathrm{C} \mathrm{NMR}\left(\mathrm{CDCl}_{3}\right)$ $\delta 138.5,137.9,128.4,127.3,115.3,74.9,72.0,64.2,37.8$.

( \pm )-[1-(2-Benzyloxyethyl)-allyloxy]-t-butyldimethylsilane (8). To a stirred solution of tertiary alcohol 7 (138.4 mg, 0.72 $\mathrm{mmol})$ and 2,6-lutidine $(0.6 \mathrm{~mL}, 6.14 \mathrm{mmol})$ in dry methylene chloride $(10 \mathrm{~mL})$ was added $t$-butyldimethylsilyltrifluoromethane sulfonate (TBDMSOTf, $0.9 \mathrm{~mL}, 3.07 \mathrm{mmol}$ ) at $-10{ }^{\circ} \mathrm{C}$. The reaction mixture was warmed to room temperature, and stirred for $3 \mathrm{~h}$ at the same temperature. The mixture was quenched by saturated sodium bicarbonate $(5 \mathrm{~mL})$ and water $(60 \mathrm{~mL})$ was added. The mixture was extracted with ethyl acetate (70 $\mathrm{mL}$ ) twice. The combined organic layer was washed with brine, dried over anhydrous sodium sulfate, filtered, and concentrated to dryness. The residue was purified by silica gel column chromatography (EtOAc/hexane, 1:35) to give $8(185 \mathrm{mg}, 84 \%)$ as a colorless oil: ${ }^{1} \mathrm{H} \mathrm{NMR}\left(\mathrm{CDCl}_{3}, 300 \mathrm{MHz}\right) \delta$ 7.28-7.22 (m, 5H), $5.90(\mathrm{~m}, 1 \mathrm{H}), 5.22(\mathrm{dd}, J=2.4,12.4 \mathrm{~Hz}, 1 \mathrm{H}), 5.15(\mathrm{~d}, J=6.9$ $\mathrm{Hz}, 1 \mathrm{H}), 4.65(\mathrm{~s}, 2 \mathrm{H}), 3.92(\mathrm{~m}, 1 \mathrm{H}), 3.40(\mathrm{t}, J=7.0 \mathrm{~Hz}, 2 \mathrm{H}), 1.68$ $(\mathrm{m}, 2 \mathrm{H}), 0.81(\mathrm{~s}, 9 \mathrm{H}), 0.02(\mathrm{~s}, 6 \mathrm{H}) ;{ }^{13} \mathrm{C} \mathrm{NMR}\left(\mathrm{CDCl}_{3}\right) \delta 138.8$, 138.1, 129.2, 127.7, 116.4, 75.3, 71.8, 63.2, 38.2, 25.6, 18.6, -5.5 .

( \pm )-3-( $t$-Butyldimethylsilanyloxy)-pent-4-en-1-ol (9). Ammonia (approximately $10 \mathrm{~mL}$ ) was condensed into a flask containing a solution of benzyl ether $8(167 \mathrm{mg}, 0.546 \mathrm{mmol})$ in dry tetrahydrofuran $(4 \mathrm{~mL})$ at $-78^{\circ} \mathrm{C}$. To this mixture was added a minimum amount of metallic lithium sufficient to maintain a blue color, and the resulting deep blue solution was stirred at $-78{ }^{\circ} \mathrm{C}$ for $4 \mathrm{~min}$. Methanol was added dropwise at the same temperature until the blue color disappeared. The colorless solution was stirred for $30 \mathrm{~min}$ at $-78^{\circ} \mathrm{C}$, and then solid ammonium chloride ( $c a .4 .0 \mathrm{~g}$ ) was added. After stirring for $1 \mathrm{~h}$ at $-78^{\circ} \mathrm{C}$, ammonia was allowed to evaporate. Diethyl ether $(40 \mathrm{~mL})$ was added, and the mixture was dried over anhydrous sodium sulfate, filtered, and concentrated in vacuo. The residue was purified by silica gel column chromatography (EtOAc/hexane, 1:15) to give 9 (101 mg, 86\%) as a colorless oil: ${ }^{1} \mathrm{H} \mathrm{NMR}\left(\mathrm{CDCl}_{3}, 300\right.$ 
$\mathrm{MHz}) \delta 5.89(\mathrm{~m}, 1 \mathrm{H}), 5.27(\mathrm{~d}, J=12.4 \mathrm{~Hz}, 1 \mathrm{H}), 5.14(\mathrm{~d}, J=$ $7.0 \mathrm{~Hz}, 1 \mathrm{H}), 3.91(\mathrm{~m}, 1 \mathrm{H}), 3.56(\mathrm{~m}, 2 \mathrm{H}), 1.66(\mathrm{~m}, 2 \mathrm{H}), 0.82(\mathrm{~s}$, $9 \mathrm{H}), 0.02(\mathrm{~s}, 6 \mathrm{H}) ;{ }^{13} \mathrm{C} \mathrm{NMR}\left(\mathrm{CDCl}_{3}\right) \delta 138.5,115.7,70.8,59.2$, $42.5,25.7,18.4,-5.6$.

$( \pm)-3-(t$-Butyldimethylsilanyloxy)-pent-4-enal (10). To a stirred solution of oxalyl chloride $(132 \mathrm{mg}, 1.04 \mathrm{mmol})$ in $\mathrm{CH}_{2} \mathrm{Cl}_{2}(8 \mathrm{~mL})$ was added a solution of DMSO (122 mg, 1.56 $\mathrm{mmol})$ in $\mathrm{CH}_{2} \mathrm{Cl}_{2}(2.5 \mathrm{~mL})$ dropwise at $-78{ }^{\circ} \mathrm{C}$. The resulting solution was stirred at $-78{ }^{\circ} \mathrm{C}$ for $10 \mathrm{~min}$, and a solution of alcohol 9 (114.6 mg, $0.53 \mathrm{mmol}$ ) in $\mathrm{CH}_{2} \mathrm{Cl}_{2}(5 \mathrm{~mL})$ was added dropwise. The mixture was stirred at $-78^{\circ} \mathrm{C}$ for $20 \mathrm{~min}$ and TEA (316 mg, $3.12 \mathrm{mmol}$ ) was added. The resulting mixture was warmed to $0{ }^{\circ} \mathrm{C}$ and stirred for $30 \mathrm{~min} . \mathrm{H}_{2} \mathrm{O}(10 \mathrm{~mL})$ was added, and the solution was stirred at room temperature for $20 \mathrm{~min}$. The mixture was diluted with water $(60 \mathrm{~mL})$ and then extracted with EtOAc $(70 \mathrm{~mL})$ twice. The combined organic layer was washed with brine, dried over anhydrous $\mathrm{MgSO}_{4}$ and filtered. The filtrate was concentrated under reduced pressure and the residue was purified by silica gel column chromatography (EtOAc/hexane, 1:20) to give aldehyde compound $\mathbf{1 0}$ (101 mg, $89 \%)$ as a colorless oil: ${ }^{1} \mathrm{H}$ NMR $\left(\mathrm{CDCl}_{3}, 300 \mathrm{MHz}\right) \delta 9.90(\mathrm{~s}$, $1 \mathrm{H}), 5.91(\mathrm{~m}, 1 \mathrm{H}), 5.29(\mathrm{dd}, J=2.6,12.2 \mathrm{~Hz}, 1 \mathrm{H}), 5.17(\mathrm{dd}, J=$ 2.7, $7.0 \mathrm{~Hz}, 1 \mathrm{H}), 4.09(\mathrm{~m}, 1 \mathrm{H}), 2.61(\mathrm{~m}, 2 \mathrm{H}), 0.82(\mathrm{~s}, 9 \mathrm{H}), 0.01$ $(\mathrm{s}, 6 \mathrm{H}) ;{ }^{13} \mathrm{C} \mathrm{NMR}\left(\mathrm{CDCl}_{3}\right) \delta 200.3,137.8,116.1,68.4,53.2$, $25.5,18.6,-5.3$.

(rel)-(3R and 3S,5S)-5-( $t$-Butyldimethylsilanyloxy)-hepta1,6-dien-3-ol (11). Divinyl derivative 11 was synthesized from aldehyde $\mathbf{1 0}$ using a similar procedure as described for $\mathbf{7}$ as a diastereomeric mixture: yield $81 \% ;{ }^{1} \mathrm{H} \mathrm{NMR}\left(\mathrm{CDCl}_{3}, 300 \mathrm{MHz}\right)$ $\delta$ 5.82-5.77 (m, 2H), 5.31-5.20 (m, 4H), 3.93-3.85 (m, 2H), 1.69$1.61(\mathrm{~m}, 2 \mathrm{H}), 0.82(\mathrm{~m}, 9 \mathrm{H}), 0.02(\mathrm{~m}, 6 \mathrm{H}) ;{ }^{13} \mathrm{C} \mathrm{NMR}\left(\mathrm{CDCl}_{3}\right) \delta$ 138.2, 137.6, 118.5, 117.6, 69.1, 68.3, 46.7, 25.7, 18.3, -5.5.

$( \pm)-5$-( $t$-Butyldimethylsilanyloxy)-hepta-1,6-dien-3-one (12). To a mixture of allylic alcohol 11 (1.2 g, $4.97 \mathrm{mmol})$, manganese (IV) dioxide (1.29 g, $14.8 \mathrm{mmol})$ and $\mathrm{CCl}_{4}(15 \mathrm{~mL})$ were stirred at room temperature. Additional manganese (IV) dioxide (216 mg, $2.47 \mathrm{mmol}$ ) was added at $1 \mathrm{~h}$. The progress of the reaction was monitored by TLC. The resulting mixture was filtered through a pad of Celite and washed with ethyl acetate. The filtrate and washings were condensed in vacuo and the residue was purified by silica gel column chromatography (EtOAc/hexane, 1:20) to give dieneone $12(896 \mathrm{mg}, 75 \%)$ as a colorless oil. ${ }^{1} \mathrm{H} \mathrm{NMR}\left(\mathrm{CDCl}_{3}, 300 \mathrm{MHz}\right) \delta 6.40-6.23(\mathrm{~m}, 4 \mathrm{H})$, $5.23(\mathrm{~m}, 2 \mathrm{H}), 3.16$ (dd, $J=12.4,6.6 \mathrm{~Hz}, 1 \mathrm{H}), 0.83(\mathrm{~s}, 9 \mathrm{H}), 0.02$ $(\mathrm{s}, 6 \mathrm{H}) ;{ }^{13} \mathrm{C} \mathrm{NMR}\left(\mathrm{CDCl}_{3}\right) \delta 197.5,139.1,138.5,128.3,116.2$, $68.7,50.5,25.4,18.7,-5.3$.

(rel)-(1R and $1 S, 4 S)-4-(t$-Butyldimethylsilanyloxy)-3-methyl-hepta-1,6-dien-3-ol (13). To a solution of compound 12 $(2.8 \mathrm{~g}, 11.66 \mathrm{mmol})$ in dry diethyl ether $(60 \mathrm{~mL})$, methyllithium $(8.7 \mathrm{~mL}, 1.6 \mathrm{M}$ solution in diethyl ether) was added slowly at $-78^{\circ} \mathrm{C}$. After $1 \mathrm{~h}$, a saturated $\mathrm{NH}_{4} \mathrm{Cl}$ solution $(15 \mathrm{~mL})$ was added, and the reaction mixture was warmed slowly to room temperature. The mixture was diluted with water $(100 \mathrm{~mL})$ and extracted with EtOAc $(100 \mathrm{~mL})$ twice. The combined organic layer was washed with water, dried over anhydrous $\mathrm{MgSO}_{4}$, filtered, and evaporated in vacuo. The residue was purified by silica gel column chromatography (EtOAc/hexane, 1:15) to give $\mathbf{1 3}$ (2.1 g, $71 \%)$ as a diastereomeric mixture: ${ }^{1} \mathrm{H} \mathrm{NMR}\left(\mathrm{CDCl}_{3}, 300 \mathrm{MHz}\right)$ $\delta 5.92-2.86(\mathrm{~m}, 2 \mathrm{H}), 5.31-5.20(\mathrm{~m}, 4 \mathrm{H}), 3.88(\mathrm{~m}, 1 \mathrm{H}), 1.65-1.60$ $(\mathrm{m}, 2 \mathrm{H}), 1.42(\mathrm{~s}, 3 \mathrm{H}), 0.81(\mathrm{~s}, 9 \mathrm{H}), 0.01(\mathrm{~s}, 6 \mathrm{H}) ;{ }^{13} \mathrm{CNMR}\left(\mathrm{CDCl}_{3}\right)$ $\delta 143.1,140.8,115.5,113.2,67.3,65.2,52.7,25.7,18.3,-5.4$.

(rel)-(1S,4S)-4-(t-Butyldimethylsilanyloxy)-1-methyl-cyclopent-2-enol (14a) and (rel)-(1R,4S)-4-(t-butyldimethylsilanyloxy)-1-methyl-cyclopent-2-enol (14b). To a solution of $\mathbf{1 3}$ (456 mg, $1.78 \mathrm{mmol})$ in dry methylene chloride $(7 \mathrm{~mL})$ was added 2 nd generation Grubbs catalyst (36.0 mg $0.0424 \mathrm{mmol}$ ). The reaction mixture was refluxed overnight and cooled to room temperature. The mixture was concentrated in vacuo, and the residue was purified by silica gel column chromatography (EtOAc/hexane, 1:10) to give cyclopentenol 14a (166 mg, 41\%) and 14b (162 mg, 40\%). Data for 14a: ${ }^{1} \mathrm{H}$ NMR $\left(\mathrm{CDCl}_{3}, 300\right.$ MHz) $\delta 5.64-5.55(\mathrm{~m}, 2 \mathrm{H}), 4.06(\mathrm{~m}, 1 \mathrm{H}), 2.17(\mathrm{dd}, J=12.2,6.8$ $\mathrm{Hz}, 1 \mathrm{H}), 2.08(\mathrm{dd}, J=12.1,8.6 \mathrm{~Hz}, 1 \mathrm{H}), 1.45(\mathrm{~s}, 3 \mathrm{H}), 0.81(\mathrm{~m}$, 9H), $0.02(\mathrm{~m}, 6 \mathrm{H}) ;{ }^{13} \mathrm{CNMR}\left(\mathrm{CDCl}_{3}\right) \delta 135.1,130.6,71.4,67.4$, 47.7, 26.7, 25.4, 18.3, -5.5; Anal. Calc. for $\mathrm{C}_{12} \mathrm{H}_{24} \mathrm{O}_{2} \mathrm{Si}$ : C, 63.10; $\mathrm{H}, 10.59$; Found: C, 63.04; H, 10.56; Data for 14b: ${ }^{1} \mathrm{H}$ NMR $\left(\mathrm{CDCl}_{3}, 300 \mathrm{MHz}\right) \delta 5.62-5.53(\mathrm{~m}, 2 \mathrm{H}), 4.10(\mathrm{~m}, 1 \mathrm{H}), 2.18(\mathrm{dd}$, $J=12.2,6.6 \mathrm{~Hz}, 1 \mathrm{H}), 2.07$ (dd, $J=12.2,8.8 \mathrm{~Hz}, 1 \mathrm{H}), 1.49$ (s, $3 \mathrm{H}), 0.82(\mathrm{~m}, 9 \mathrm{H}), 0.01(\mathrm{~m}, 6 \mathrm{H}) ;{ }^{13} \mathrm{C} \mathrm{NMR}\left(\mathrm{CDCl}_{3}\right) \delta 136.3$, 131.4, 70.9, 66.8, 48.9, 26.2, 25.7, 18.6, -5.3; Anal. Calc. for $\mathrm{C}_{12} \mathrm{H}_{24} \mathrm{O}_{2} \mathrm{Si}$ : C, 63.10; H, 10.59; Found: C, 63.15; H, 10.66.

(rel)-(1'R,4'S)-9-[4-(t-Butyldimethylsilanyloxy)-1-methylcyclopent-2-enyl]-6-chloropurine (15). To a solution containing compound 14b $(66.46 \mathrm{mg}, 0.291 \mathrm{mmol})$, triphenylphosphine (305 mg, $1.164 \mathrm{mmol}$ ) and 6-chloropurine (90 mg, $0.582 \mathrm{mmol}$ ) in anhydrous co-solvent (dioxane/DMF:3/1, $7.0 \mathrm{~mL}$ ), diisopropyl azodicarboxylate (DIAD) (117 mg, $0.582 \mathrm{mmol}$ ) was added dropwise at $-78{ }^{\circ} \mathrm{C}$ for $30 \mathrm{~min}$ under nitrogen. The reaction mixture was stirred for $2 \mathrm{~h}$ at $-20{ }^{\circ} \mathrm{C}$ under nitrogen and further stirred for $2 \mathrm{~h}$ at $\mathrm{rt}$. The solvent was concentrated under reduced pressure and the residue was purified by silica gel column chromatography (EtOAc/hexane, 2:1) to give compound 15 (46 mg, 44\%): ${ }^{1} \mathrm{H} \mathrm{NMR}\left(\mathrm{CDCl}_{3}, 300 \mathrm{MHz}\right) \delta 8.77(\mathrm{~s}, 1 \mathrm{H})$, $8.54(\mathrm{~s}, 1 \mathrm{H}), 5.62-5.55(\mathrm{~m}, 2 \mathrm{H}), 4.09(\mathrm{~m}, 1 \mathrm{H}), 2.17$ (dd, $J=$ $12.3,6.8 \mathrm{~Hz}, 1 \mathrm{H}), 2.07$ (dd, $J=12.2,8.8 \mathrm{~Hz}, 1 \mathrm{H}), 1.89$ (s, 3H), $0.81(\mathrm{~m}, 9 \mathrm{H}), 0.01(\mathrm{~m}, 6 \mathrm{H}) ;{ }^{13} \mathrm{C} \mathrm{NMR}\left(\mathrm{CDCl}_{3}\right) \delta 154.7,152.3$, 147.6, 145.7, 134.3, 129.4, 123.5, 70.5, 57.4, 46.7, 25.4, 23.8, 18.5, -5.3; Anal. Calc. for $\mathrm{C}_{17} \mathrm{H}_{25} \mathrm{ClN}_{4} \mathrm{OSi} \cdot 1.0 \mathrm{MeOH}$ : C, 54.46; H, 7.36; N, 14.11; Found: C, 54.49; H, 7.40; N, 14.08.

(rel)-(1'R,4'S)-9-[4-Hydroxy-1-methyl-cyclopent-2-en-1-yl] 6-chloropurine (16). To a solution of $\mathbf{1 5}$ (126 mg, $0.345 \mathrm{mmol}$ ) in THF $(6.0 \mathrm{~mL})$, TBAF $(0.449 \mathrm{~mL}, 1.0 \mathrm{M}$ solution in THF $)$ was added at $0{ }^{\circ} \mathrm{C}$. The mixture was stirred overnight at room temperature and concentrated in vacuo. The residue was purified by silica gel column chromatography $(\mathrm{MeOH} / \mathrm{Hexane} / \mathrm{EtOAc}$, 0.05:4:1) to give 16 (94 mg, 84\%) as a white solid: mp 156 $158{ }^{\circ} \mathrm{C} ;{ }^{1} \mathrm{H}$ NMR (DMSO- $\left.d_{6}, 300 \mathrm{MHz}\right) \delta 8.79$ (s, 1H), 8.55 (s, $1 \mathrm{H}), 5.56-5.47(\mathrm{~m}, 2 \mathrm{H}), 5.17\left(\mathrm{~s}, 1 \mathrm{H}, \mathrm{D}_{2} \mathrm{O}\right.$ exchangeable $), 4.12$ $(\mathrm{m}, 1 \mathrm{H}), 2.56(\mathrm{dd}, J=12.3,6.8 \mathrm{~Hz}, 1 \mathrm{H}), 2.12(\mathrm{dd}, J=12.4,6.8$ $\mathrm{Hz}, 1 \mathrm{H}), 1.85(\mathrm{~s}, 3 \mathrm{H}) ;{ }^{13} \mathrm{C}$ NMR (DMSO- $\left.d_{6}\right) \delta 155.0,153.5$, 147.3, 135.2, 128.6, 127.2, 123.2, 72.1, 58.5, 44.8, 23.6; Anal. Calc. for $\mathrm{C}_{11} \mathrm{H}_{11} \mathrm{ClN}_{4} \mathrm{O}$ : C, 52.70; H, 4.42; N, 22.35; Found: C, 52.67; H, 4.39; N, 22.33.

(rel)-(1'R,4'S)-Diethyl [9-(4-hydroxy-1-methyl-cyclopent2-en-1-yl)] 6-chloropurine] methylphosphonate (17). Both $\mathrm{LiO} t-\mathrm{Bu}(3.8 \mathrm{~mL}$ of $0.5 \mathrm{M}$ solution in THF, $1.9 \mathrm{mmol})$ and a 
solution of diethyl phosphonomethyltriflate $(480 \mathrm{mg}, 1.6 \mathrm{mmol})$ in $5.0 \mathrm{~mL}$ of THF were slowly added to a solution of the purine analogue $16(296 \mathrm{mg}, 1.18 \mathrm{mmol})$ in $5.0 \mathrm{~mL}$ of THF at $0{ }^{\circ} \mathrm{C}$ and stirred for $4 \mathrm{~h}$ at $\mathrm{rt}$ under anhydrous conditions. The mixture was quenched by adding water $(5 \mathrm{~mL})$ and further diluted with additional $\mathrm{H}_{2} \mathrm{O}(50 \mathrm{~mL})$. The aqueous layer was extracted with EtOAc $(3 \times 50 \mathrm{~mL})$. The combined organic layer was washed with brine, dried over anhydrous $\mathrm{MgSO}_{4}$, and concentrated in vacuo. The residue was purified by silica gel column chromatography (MeOH/Hexane/EtOAc, 0.05:3:1) to give 17 (274 mg, $58 \%$ ) as a foamy solid: $\mathrm{mp} 109-111{ }^{\circ} \mathrm{C} ;{ }^{1} \mathrm{H}$ NMR $\left(\mathrm{CDCl}_{3}, 300\right.$ $\mathrm{MHz}) \delta 8.78(\mathrm{~s}, 1 \mathrm{H}), 8.54(\mathrm{~s}, 1 \mathrm{H}), 5.56-5.46(\mathrm{~m}, 2 \mathrm{H}), 4.29-4.15$ $(\mathrm{m}, 6 \mathrm{H}), 3.68(\mathrm{~d}, J=8.0 \mathrm{~Hz}, 2 \mathrm{H}), 2.54(\mathrm{dd}, J=12.3,6.5 \mathrm{~Hz}$, $1 \mathrm{H}), 2.08$ (dd, $J=12.4,8.7 \mathrm{~Hz}, 1 \mathrm{H}), 1.84(\mathrm{~s}, 3 \mathrm{H}), 1.39$ (m, 6H); $\left.{ }^{13} \mathrm{C} \mathrm{NMR}\left(\mathrm{CDCl}_{3}\right)\right) \delta 154.8,152.8,146.5,133.2,129.5,127.4$, 119.4, 71.4, 67.4, 65.3, 63.2, 57.6, 46.5, 22.9, 16.2; Anal. Calc. for $\mathrm{C}_{16} \mathrm{H}_{22} \mathrm{ClN}_{4} \mathrm{O}_{4} \mathrm{P} \cdot 1.0 \mathrm{MeOH}$ : C, 47.17; H, 6.05; N, 12.94; Found: C, 47.21; H, 6.01; N, 12.97.

(rel)-(1'R,4'S)-Diethyl [9-(4-hydroxy-1-methyl-cyclopent2-en-1-yl)] adenine] methylphosphonate (18). A solution of 17 (120 mg, $0.299 \mathrm{mmol})$ in saturated methanolic ammonia $(5 \mathrm{~mL})$ was stirred at $70{ }^{\circ} \mathrm{C}$ in a steel bomb, and the volatile components were evaporated. The residue was purified by silica gel column chromatography $\left(\mathrm{MeOH} / \mathrm{CH}_{2} \mathrm{Cl}_{2}, 1: 10\right)$ to give $\mathbf{1 8}(77 \mathrm{mg}, 68 \%)$ as a solid: mp $130-132{ }^{\circ} \mathrm{C} ;{ }^{1} \mathrm{H}$ NMR (DMSO- $\left.d_{6}, 300 \mathrm{MHz}\right) \delta$ $8.28(\mathrm{~s}, 1 \mathrm{H}), 8.10(\mathrm{~s}, 1 \mathrm{H}), 5.57-5.48(\mathrm{~m}, 2 \mathrm{H}), 4.30-4.17(\mathrm{~m}, 5 \mathrm{H})$, $3.68(\mathrm{~d}, J=8.2 \mathrm{~Hz}, 2 \mathrm{H}), 2.33(\mathrm{dd}, J=12.4,6.7 \mathrm{~Hz}, 1 \mathrm{H}), 2.05$ (dd, $J=12.3,8.8 \mathrm{~Hz}, 1 \mathrm{H}), 1.82(\mathrm{~s}, 3 \mathrm{H}), 1.37$ (t, $J=7.0 \mathrm{~Hz}, 6 \mathrm{H}) ;{ }^{13} \mathrm{C}$ NMR (DMSO- $\left.d_{6}\right) \delta 155.1,153.4,147.8,134.6,128.6,126.7$, 118.4, 70.5, 67.8, 65.3, 63.7, 58.7, 48.1, 23.4, 16.8; Anal. Calc. for $\mathrm{C}_{16} \mathrm{H}_{24} \mathrm{~N}_{5} \mathrm{O}_{4} \mathrm{P} \cdot 1.0 \mathrm{MeOH}$ : C, 49.39; H, 6.83; N, 16.94; Found: C, 49.43; H, 6.80; N, 16.91 .

(rel)-(1'R, 2'S,3'S,4'S)-Diethyl [9-(2,3-dihydroxy-1-methylcyclopent-1-yl)] adenine] 4-methylphosphonate (19) and (rel)(1'R,2'R,3'R,4'S)-diethyl [9-(2,3-dihydroxy-1-methyl-cyclopent-1-yl)] adenine] 4-methylphosphonate (20). Compound 18 $(152 \mathrm{mg}, 0.4 \mathrm{mmol})$ was dissolved in a mixture of acetone (6 mL), $t$-BuOH (1 mL), and $\mathrm{H}_{2} \mathrm{O}(1 \mathrm{~mL})$ along with 4-methylmorpholine $N$-oxide (70 mg, $0.6 \mathrm{mmol}$ ). Subsequently, $\mathrm{OsO}_{4}$ $\left(0.127 \mathrm{~mL}, 0.02 \mathrm{mmol}, 4 \% \mathrm{wt} \%\right.$ in $\left.\mathrm{H}_{2} \mathrm{O}\right)$ was added. The mixture was stirred overnight at $\mathrm{rt}$ and quenched with saturated $\mathrm{Na}_{2} \mathrm{SO}_{3}$ solution $(2 \mathrm{~mL})$. The resulting solid was removed by filtration through a pad of Celite, and the filtrate was concentrated under reduced pressure. The residue was purified by silica gel column chromatography $\left(\mathrm{MeOH} / \mathrm{CH}_{2} \mathrm{Cl}_{2}, 1: 5\right)$ to give 19 (61 mg, 37\%) and 20 (28 mg, 17\%):

Spectroscopical data for 19: $\mathrm{mp} 148-150{ }^{\circ} \mathrm{C}$; $\mathrm{UV}\left(\mathrm{H}_{2} \mathrm{O}\right) \lambda_{\max }$ $262.5 \mathrm{~nm} ;{ }^{1} \mathrm{H}$ NMR (DMSO- $\left.d_{6}, 300 \mathrm{MHz}\right) \delta 8.28$ (s, 1H), 8.15 (s, 1H), 7.15 (br s, 2H), 4.99 (d, $J=4.0 \mathrm{~Hz}, 1 \mathrm{H}), 4.21$ (m, 4H), $3.71-3.63(\mathrm{~m}, 3 \mathrm{H}), 3.31(\mathrm{~d}, J=6.8 \mathrm{~Hz}, 1 \mathrm{H}), 3.02(\mathrm{~m}, 1 \mathrm{H}), 2.12$ (dd, $J=12.4,6.8 \mathrm{~Hz}, 1 \mathrm{H}), 1.93$ (dd, $J=12.4,8.6 \mathrm{~Hz}, 1 \mathrm{H}), 1.72$ $(\mathrm{s}, 3 \mathrm{H}), 1.37(\mathrm{~m}, 6 \mathrm{H}) ;{ }^{13} \mathrm{C}$ NMR (DMSO-d $) \delta 154.9,152.4$, 149.3, 144.6, 119.8, 80.2, 71.3, 67.8, 65.9, 64.6, 63.2, 53.2, 31.6, 18.0, 16.2; Anal. Calc. for $\mathrm{C}_{16} \mathrm{H}_{26} \mathrm{~N}_{5} \mathrm{O}_{6} \mathrm{P} \cdot 1.0 \mathrm{MeOH}$ : C, 45.63; H, 6.76; N, 15.65; Found: C, 45.59; H, 6.79; N, 15.68.

Spectroscopical data for 20: $\mathrm{mp} 156-158^{\circ} \mathrm{C}$; $U V\left(\mathrm{H}_{2} \mathrm{O}\right) \lambda_{\max }$ $261.0 \mathrm{~nm} ;{ }^{1} \mathrm{H}$ NMR (DMSO- $\left.d_{6}, 300 \mathrm{MHz}\right) \delta 8.30$ (s, 1H), 8.17 (s, 1H), 7.13 (br s, 2H), 4.89 (d, J=4.2 Hz, 1H), 4.22-4.26 (m,
4H), 3.70-3.62 (m, 3H), $3.36(\mathrm{~d}, J=6.7 \mathrm{~Hz}, 1 \mathrm{H}), 3.07(\mathrm{~m}, 1 \mathrm{H})$, $2.12(\mathrm{dd}, J=12.5,6.8 \mathrm{~Hz}, 1 \mathrm{H}), 1.94(\mathrm{dd}, J=12.4,8.8 \mathrm{~Hz}, 1 \mathrm{H})$, $1.77(\mathrm{~s}, 3 \mathrm{H}), 1.38(\mathrm{~m}, 6 \mathrm{H}) ;{ }^{13} \mathrm{C} \mathrm{NMR}$ (DMSO-d $) \delta 155.1,152.8$, 148.6, 143.8, 120.3, 79.8, 71.5, 68.2, 65.2, 62.4, 54.6, 33.7, 17.6, 15.9; Anal. Calc. for $\mathrm{C}_{16} \mathrm{H}_{26} \mathrm{~N}_{5} \mathrm{O}_{6} \mathrm{P} \cdot 1.5 \mathrm{MeOH}$ : C, 45.35; $\mathrm{H}$, $6.96 ;$ N, 15.11; Found: C, 45.31; H, 7.00; N, 15.08.

(rel)-(1'R,2'S,3'S,4'S)-[9-(2,3-dihydroxy-1-methyl-cyclopent-1-yl)] adenine] 4-methylphosphonic acid (21): To a solution of the phosphonate $19(87 \mathrm{mg}, 0.211 \mathrm{mmol})$ in anhydrous $\mathrm{CH}_{3} \mathrm{CN}(7 \mathrm{~mL})$ and 2,6-lutidine $(0.5 \mathrm{~mL})$ was added trimethylsilyl bromide (350 mg, $2.3 \mathrm{mmol})$. The mixture was heated under reflux for $6 \mathrm{~h}$ and then concentrated under reduced pressure. The residue was partitioned between $\mathrm{CH}_{2} \mathrm{Cl}_{2}(50 \mathrm{~mL})$ and distilled clean water $(50 \mathrm{~mL})$. The aqueous layer was washed out with $\mathrm{CH}_{2} \mathrm{Cl}_{2}$ two times and then freeze-dried to give target compound 21 (47 $\mathrm{mg}, 83 \%$ ) as a yellowish solid. mp $121-123$ ${ }^{\circ} \mathrm{C}$; UV $\left(\mathrm{H}_{2} \mathrm{O}\right) \lambda_{\max } 263.0 \mathrm{~nm} ;{ }^{1} \mathrm{H}$ NMR (DMSO- $\left.d_{6}, 300 \mathrm{MHz}\right)$ $\delta 8.29(\mathrm{~s}, 1 \mathrm{H}), 8.14(\mathrm{~s}, 1 \mathrm{H}), 5.01(\mathrm{br} \mathrm{s}, 1 \mathrm{H}), 3.72-3.66(\mathrm{~m}, 3 \mathrm{H})$, $3.41(\mathrm{~d}, J=6.6 \mathrm{~Hz}, 1 \mathrm{H}), 3.09(\mathrm{~m}, 1 \mathrm{H}), 2.21(\mathrm{dd}, J=12.4,6.7 \mathrm{~Hz}$, 1H), $1.98(\mathrm{dd}, J=12.5,8.9 \mathrm{~Hz}, 1 \mathrm{H}), 1.69(\mathrm{~s}, 3 \mathrm{H}) ;{ }^{13} \mathrm{C} \mathrm{NMR}$ $\left(\mathrm{DMSO}-d_{6}\right) \delta 155.1,153.7,148.3,145.8,121.0,80.1,78.6,73.2$, 67.5, 64.2, 53.1, 31.4; Anal. Calc. for $\mathrm{C}_{12} \mathrm{H}_{18} \mathrm{~N}_{5} \mathrm{O}_{6} \mathrm{P} \cdot 3.0 \mathrm{H}_{2} \mathrm{O}$ : C, 34.87; H, 5.85; N, 16.94; Found: C, 34.92; H, 5.82; N, 16.95.

\section{References}

1. (a) Takenuki, K.; Matsuda, A.; Ueda, T.; Sasaki, T.; Fujii, A.; Yamagami, K. J. Med. Chem. 1988, 31, 1063. (b) Yamagami, K.; Fujii, A.; Arita, M.; Okumoto, T.; Sakata, S.; Matsuda, A.; Ueda, T.; Sasaki, T. Cancer Res. 1991, 51, 2319.

2. (a) Matsuda, A.; Nakajima, Y.; Azuma, A.; Tanaka, M.; Sasaki, T. J. Med. Chem. 1991, 34, 2917. (b) Azuma, A.; Nakajima, Y.; Nishizono, N.; Minakawa, N.; Suzuki, M.; Hanaoka, K.; Kobayashi, T.; Tanaka, M.; Sasaki, T.; Matsuda, A. J. Med. Chem. 1993, 36, 4183.

3. (a) Hattori, H.; Tanaka, M.; Fukushima, M.; Sasaki, T.; Matsuda, A. J. Med. Chem. 1996, 39, 5005. (b) Hattori, H.; Nozawa, E.; Iino, T.; Yoshimura, Y.; Shuto, S.; Shimamoto, Y.; Nomura, M.; Fukushima, M.; Tanaka, M.; Sasaki, T.; Matsuda, A. J. Med. Chem. 1998, 41, 2892.

4. Sugimoto, I.; Shuto, S.; Mori, S.; Shigeta, S.; Matsuda, A. Bioorg. Med. Chem. Lett. 1999, 9, 385.

5. Nomura, M.; Shuto, S.; Tanaka, M.; Sasaki, T.; Mori, S.; Shigeta, S.; Matsuda, A. J. Med. Chem. 1999, 42, 2901.

6. (a) Yuntsen, H.; Ohkuma, K.; Ishii, Y. J. Antibiot. 1956, 9A, 195. (b) Haraguchi, K.; Kubota, Y.; Tanaka, H. J. Org. Chem. 2004, 69, 1831.

7. (a) Nakajima, M.; Itoi, K.; Takamatsu, Y. Y.; Kinoshita, T.; Okazaki, T.; Kawakubo, K.; Shindo, M.; Honma, T.; Tohjigamor, M.; Haneishi, T. J. Antibiot. 1991, 44, 293. (b) Mio, S.; Sano, H.; Shindo, M.; Honma, T.; Sugai, S. Agri. Biol. Chem. 1991, 55, 1105.

8. (a) Mahmood, K.; Vasella, A.; Bernet, B. Helv. Chem. Acta 1991, 74, 1555. (b) Elliot, R. D.; Niwas, S.; Riordan, J. M.; Montgomery, J. A.; Secrist, J. A., III. Nucleosides Nucleotides 1992, 11, 97. (c) Faivre-Buet, V.; Grouiller, A.; Descotes, G. Nucleosides Nucleotides 1992, 11, 1651. (d) Uteza, V.; Chen, G.-H.; Tuoi, J. L. Q.; Descotes, G.; Fenet, B.; Grouiller, A. Tetrahedron 1993, 49, 8579. (e) Kodama, T.; Shuto, S.; Nomura, M.; Matsuda, A. Chem. Eur. J. 2001, 7, 2332.

9. (a) Mackman, R. L.; Boojamra, C. G.; Prasad, V.; Zhang, L.; Lin, K. Y.; Petrakovsky, O.; Babusis, D.; Chen, J.; Douglas, J.; Grant, D.; Hui, H. C.; Kim, C. U.; Markevitch, D. Y.; Vela, J.; Ray, A.; Cihlar, T. Bioorg. Med. Chem. Lett. 2007, 17, 6785. (b) Ray, A. S.; Vela, J. E.; Boojamra, C. G.; Zhang, L.; Hui, H.; Callebaut, 
C.; Stray, K.; Lin, K. Y.; Gao, Y.; Mackman, R. L.; Cihlar, T. Antimicrob. Agents Chemother. 2008, 52, 648.

10. (a) Mackman, R. L.; Boojamra, C. G.; Prasad, V.; Zhang, L.; Lin, K. Y.; Petrakovsky, O.; Babusis, D.; Chen, J.; Douglas, J.; Grant, D.; Hui, H. C.; Kim, C. U.; Markevitch, D. Y.; Vela, J.; Ray, A.; Cihlar, T. Bioorg. Med. Chem. Lett. 2007, 17, 6785. (b) Ray, A. S.; Vela, J. E.; Boojamra, C. G.; Zhang, L.; Hui, H.; Callebaut, C.; Stray, K.; Lin, K. Y.; Gao, Y.; Mackman, R. L.; Cihlar, T. Antimicrob. Agents Chemother. 2008, 52, 648. (c) Boojamra, C. G.; Mackman, R. L.; Markevitch, D. Y.; Prasad, V.; Ray, A. S.; Douglas, J.; Grant, D.; Kim, C. U.; Cihlar, T. Bioorg. Med. Chem. Lett. 2008, 18, 1120. (d) Mackman, R. L.; Lin, K. Y.; Boojamra, C. G.; Hui, H.; Douglas, J.; Grant, D.; Petrakovsky, O.; Prasad, V.; Ray, A. S.; Cihlar, T. Bioorg. Med. Chem. Lett. 2008, 18, 1116.

11. Wu, T.; Froeyen, M.; Kempeneers, V.; Pannecouque, C.; Wang, J.; Busson, R.; De Clercq, E.; Herdewijn, P. J. Am. Chem. Soc. 2005, 127,5056 .

12. Kadota, I.; Yamamoto, Y. J. Org. Chem. 1998, 63, 6597.
13. (a) Kim, A.; Hong, J. H. Arch. Pharm. 2005, 338, 522. (b) Kim, A.; Hong, J. H. Bull. Korean Chem. Soc. 2006, 27, 976. (c) Jeong, L. S.; Lee, J. A. Antiviral Chem. Chemother. 2004, 15, 235.

14. (a) Phillion, D. P.; Andrew, S. S. Tetrahedron Lett. 1986, 27, 1477. (b) Xu, Y.; Flavin, M. T. Xu, Z.-Q. J. Org. Chem. 1996, 61, 7697.

15. Boojamra, C. G.; Parrish, J. P.; Sperandio, D.; Gao, Y.; Petrakovsky, O. V.; Lee, S. K.; Markevitch, D. Y.; Vela, J. E.; Laflamme, G.; Chen, J. M.; Ray, A. S.; Barron, A. C.; Sparacino, M. L.; Desai, M. C. Kim, C. U.; Cihlar, T.; Mackman, R. L. Bioorg. Med. Chem. 2009, 17, 1739.

16. Koh, Y. H.; Shim, J. H.; Wu, J. Z.; Zhong, W.; Hong, Z.; Girardet, J. L. J. Med. Chem. 2005, 48, 2867.

17. Trost, B. M.; Kuo, G. H.; Benneche, T. J. Am. Chem. Soc. 1988 , 110,621

18. Hocková, D.; Holý, A.; Masojídková, M.; Keough, D. T.; de Jersey, J.; Guddat, L. W. Bioorg. Med. Chem. 2009, 17, 6218.

19. Lian, L. J.; Yoo, J. C.; Hong, J. H. Nucleosides Nucleotides Nucleic Acids 2009, 28, 150. 